\title{
Diversity of some aquatic and aerial odonatous dwellers of the River Nile in Upper Egypt
}

\author{
Mohamed Z. Y. Aly ${ }^{1}$; Khalid S. M. Osman ${ }^{2}$; Ibraheem E. E. ${ }^{3}$; Ahmed M. Nour ${ }^{4}$ \\ Department of Zoology, Faculty of Science, South Valley University
}

\section{ABSTRACT}

The present work is aimed to study diversity of odonatous adults and naiads species encountered in the River Nile current throughout Upper Egypt. This study has been curried out in five stations for two sequence years. The odonatous diversity was investigated by monitoring numerical, locality abundance, and periodical abundance diversity.

The numerical diversity showed eight odonatous species. Moreover, the adults ( $54.75 \%$ of the total catches) dominated the naiads (45.25\%) as well as Lestidae and Lestes viridis on the levels of the families and species.

Regarding locality diversity, the highest abundance of adults and nymphs were recorded in two different sites (El-Mashtal and Banana Island stations, respectively). Conversely, the lowest populations were recorded in Menshaa station.

On the other hand, the periodical abundance diversity indicated to importance of the two seasons, winter and summer during which the highest seasonal abundance for the naiads and the adults, respectively, in the most studied stations. In contrast, the minimum abundances of the naiads and adults were recorded during spring and winter, respectively. Thus, it could be seen seasonal abundant interference for both nymphs and adults, particularly, during spring. This result may be due to the long ages of the nymphs.

The variation of the seasonal abundance exceptive stations may not affect on the importance of winter and spring as the periods of the highest and lowest seasonal abundances because perhaps these stations, especially stations $\mathrm{Ma}$, underwent some of the human activities of the commercial ports.

\section{INTRODUCTION}

Ecological diversity represents the vertebrate of most various ecological sciences. That means, insect diversity supports and couple with other different insect ecologies for examples population ecology and systematic entomology even with insect microbiology. Entomo-ecological diversity could be performed by investigating abundance and dominance of the insect group. On the other hand, one of the very important insect groups is the odonates because of their ecological rule and biological control they play. Therefore, the odonatous species occupy an important position among the different hexapods.

All over the world, several authors studied the ecology of some species of order Odonata (Muller, 1993; Vantol and Rozendaal, 1995; Shukla and Shrivastava, 2003; Katherine, 2005; Mukherji et al., (2005); Abushama (2006); Beschovski and Marinov (2007); Brooks (2008) Lorenzo-Carballa and Cordero-Rivera (2009). Abbott (2001) worked on the distribution of dragonflies and damselflies (Odonata) in Texas. In Malaysia, Norma-Rashid, et al. (2001) studied diversity and distribution of Odonata 
in the fresh water swamp lake. Schultz et al., (2003) studied the assessment of the ecological status of Danubian floodplains at Tulln (Lower Austria) based on the Odonata Habitat. Stoks and McPeek (2003) surveyed data from New England and showed that assemblages of Lestes damselflies are organized along the entire gradient of pond permanence and predator presence. Raab (2004) studied between 1995 and 2000, the floodplain of the River Danube near Regelsbrunn, Austria, for dragonfly species in a before and after study: Results indicated that 32 species were recorded at the before and 37 species at the after study with a total of 41 dragonfly species.

Several studies have been conducted on the abundance of Odonata species (Galbreath and Hendricks, 1992; Bath and Kaur, 1998; Alonso et al., 2002 and Borisov, 2006). Olsvik and Dolmen (1992) studied distribution habitat, and conservation status of threatened Odonata in Norway. Ali et al., (2002) investigated the abundance and biomass of the naiads of two odonata species, Ischnura evanci and Brachythemis fuscopalliata, in the Qaramat Ali region near Basrah. Abbott et al., (2003) noticed the distribution of Odonata in the Texas Panhandle, with a summary of new state and county records. Bried et al., (2005) studied the community and conservation ecology of dragonfly and damselfly adults in Mississippi wetlands. Hofmann and Christopher (2005) studied the influence of habitat characteristics on the distribution of larval and adult Odonata communities in a lowland river in eastern England. Butler and DeMaynadier (2007) studied the significance of littoral and shoreline habitat integrity to conservation of lacustrine damselflies (Odonata). Kalkman et al., (2008) reported that the order Odonata is relatively well studied, and the actual number of species may be close to 7,000. Many species have small distributional ranges, and are habitat specialists, including inhabitants of alpine mountain bogs, seepage areas in tropical rain forests and waterfalls.

In Africa, several studies have been carried out with Odonata. Samways and Steytler (1996) studied the dragonfly (Odonata) distribution patterns in urban and forest landscapes and stated recommendations for riparian management. Vick (2002) studied the preliminary biodiversity assessment of the Odonata fauna of the Takamanda Forest Reserve, Cameron. He stated that, the African dragonfly fauna about 900 species and 125 genera. Finch et al., (2006) selected a simple modeling approach for the generation of distribution maps from a limited dataset, as a first step to the atlas sing of Odonata in South Africa.

In Egypt, few authors studied the ecology of aquatic insects such as Shoukry (1979) who conducted a survey of adult Odonata in Hihya, Abu Hammad, Zagazig and Minyat El-Kamh, he reported that, most species were found near aquatic habitats ponds, streams and the lake. Tawfik (1986) studied aquatic insect in swimming pools. Aly et al., (1992) reported a general survey and seasonal distribution of aquatic insects in Qena Governorate, Egypt. Aly et al., (1993) studied the seasonal abundance and effect of Chemo-physical factors on immature stages of order Odonata in Qena. Abdel-Aal et al., (1998) studied the biological control and ecology of mosquitoes in Aswan. The species composition and relative abundance of some odonatous species encountered in the Red Sea Governorate were investigated by Osman, 2004. Mohamed (2004) studied the ecological and behaviors on some species of order Odonata in Qena Governorate (Egypt) and Northwestern (Germany).

This work is aimed to survey the odonatous species dwelling banks and gulfs of the River Nile and some of its channels. Moreover, it is purposed to show a primitive ecological comparison between abundance of the aquatic and aerial odonatous stages. 


\section{MATERIALS AND METHODS}

The present work was carried out in and around Luxor city $(670 \mathrm{Km}$ south of Cairo) for a period of two sequence years (from March 2005 till February 2007). Five stations were visited once a weak during the day (9.30 a.m. - 1.30 p.m.), photos (1, 2 and 3 ).

The all stations are opened or semi-opened systems (Banana Island, Crocodile Island, El-Mashtal, El-Radwania and Menshaa station). The first, second and third stations are located 2.5, 3, $5 \mathrm{~km}$ far from Luxor City on the River Nile, respectively. However the fourth and fifth stations were located 5 and $6 \mathrm{~km}$ south and eastern on the River Nile (photos 1, 2 and 3).

On the other hand, there are some different plants on all stations (the vegetated area inside and around the stations) and it was consider the urban zones.

Conical sweeping net for collecting odonatous adults non cloth sweeping net for catching the nymph stages were used. Altogether, 10 sweepings formed the representative sample on each visit. These sweepings were applied at almost equal 10 meters of each station. The catch was sorted in to genera and species. Number of individuals of each species was counted.

\section{Identification of fauna:}

Identification of the caught adult and nymph odonatous specimens was performed by two methods; the first was by rearing the nymph. However the second was done by using Key of Sternberg and Buchwald (Band 1, 1999 and Band 2, 2000).

Nymphs identification were conducted by using A Key to the Italian Odonata larvae (Gianmaria, 1983) after the microscopic examination under laboratory conditions of entomology at faculty of Science, Qena, South Valley University.

Seasonal abundance: The seasonal abundance of the various species, genera, families and all order collectively were represented by histograms using the computer with exception of species represented by few individuals.

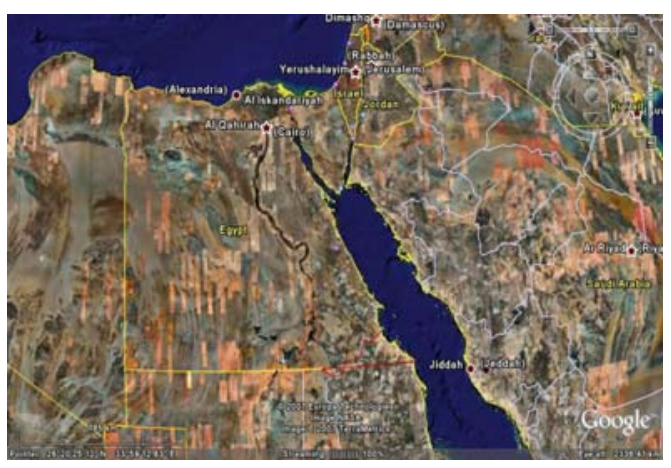

Photo (1): Egypt map.

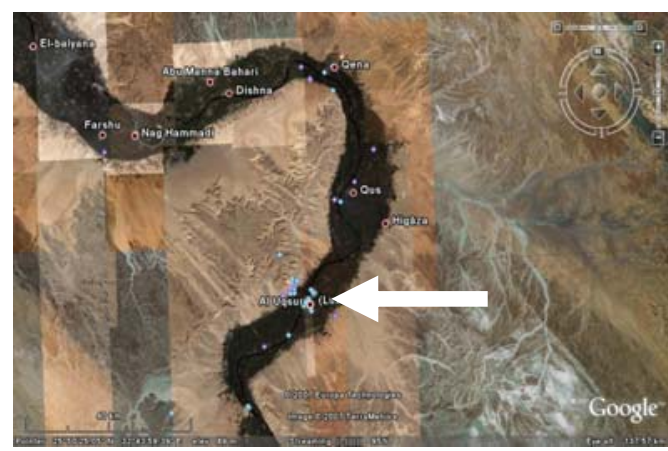

Photo (2): River Nile including location of Luxor City. 

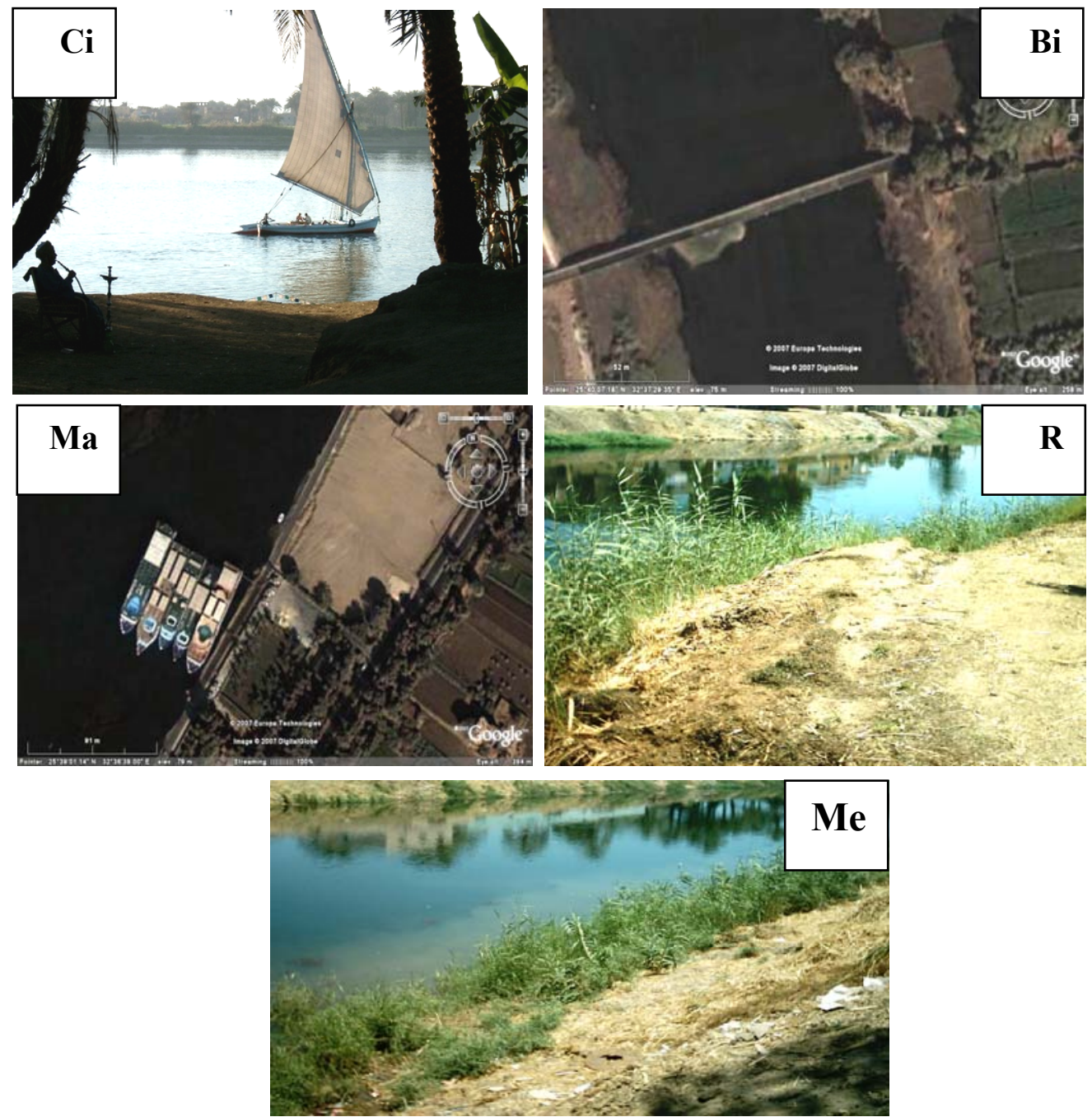

Photo (3): Pictures of Stations involving:

(Bi): Banana Island, (Ci): Crocodile Island,

(Ma): El-Mashtal, (R): El-Radwania and

(Me): Menshaa station.
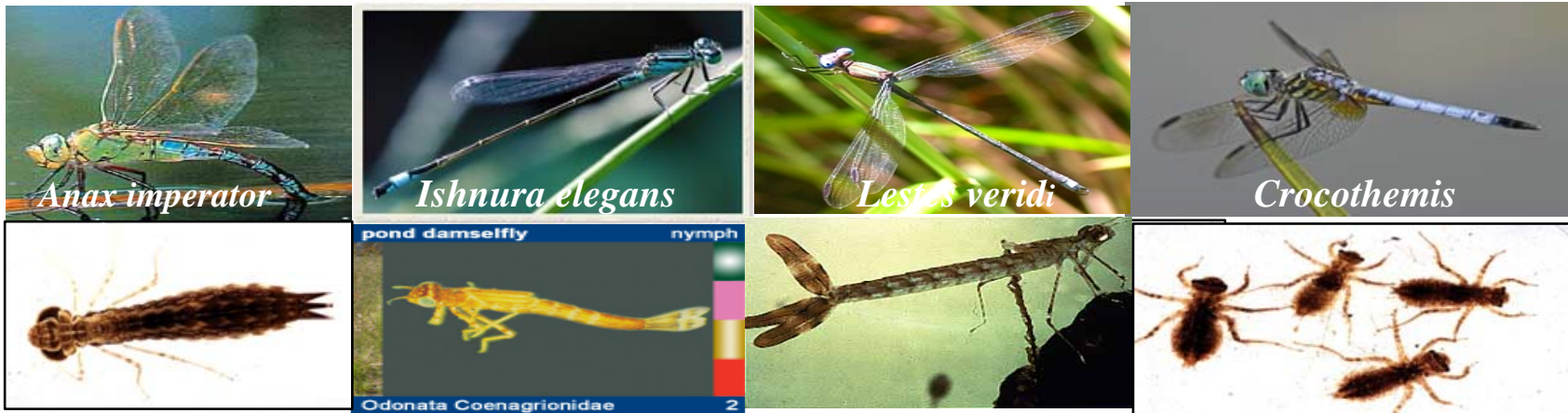

Photo 4: Some species of adults and nymphs Odonata taken by www. ucmp. berkeley. edu/.../ odonatoida. html and www.mdfrc.org.au/BugGuide/ 


\section{RESULTS AND DISCUSSION}

Results on the diversity of the odonatous showed eight species belonging to eight genera under five families. These identified families are Aeshnidae, Coenagrionidae, Gomphidae, Lestidae and Libellulidae, while their species are Aeschna cyanea, Anax imperator, Crocothemis erythraea, Enallagma cyathigerum, Ischnura elegans, Lestes viridis, Libellula fulva and Onychogomphus forcipiatus, (table 1 and photo 6). On the other hand, the diversity of these odonatous is recognised as numerical, seasonal, locality, evolutional abundance and dominance of some species.

\section{I- Numerical Diversity of Naiads and Adults:}

Numerical diversity of the odonatous naiads and adults was expressed by the total catches of all order, the different families and species. As shown in table (1), the total numbers of adult and nymph catches at all stations for two sequent years were represented by $54.75 \%$ and $45.25 \%$ of all caught odonatous, respectively. The previous result perhaps indicates to dominate adult odonatous stage comparing with other immature stages during all studied period.

Table (1): Families, genera, species and numbers of the odonatous individuals.

\begin{tabular}{|c|c|c|c|c|c|c|c|c|}
\hline \multirow{2}{*}{ Families } & \multicolumn{2}{|c|}{ No. of genera } & \multicolumn{2}{|c|}{ No.of species } & \multicolumn{2}{|c|}{$\begin{array}{c}\text { No.of } \\
\text { individuals }\end{array}$} & \multicolumn{2}{|c|}{$\%$ of the total catch } \\
\hline & A. & $\mathrm{N}$. & A. & $\mathrm{N}$. & A. & $\mathrm{N}$. & A. & $\mathrm{N}$. \\
\hline Aeshnidae & 2 & 2 & 2 & 2 & 17 & 199 & $0.18 / .08$ & $2.51 / .92$ \\
\hline Coenagrionidae & 2 & 2 & 2 & 2 & 2217 & 3024 & $23.10 /$ & 38.11 \\
\hline Gomphidae & 1 & 1 & 1 & 1 & 430 & 5 & 4.48 & 0.06 \\
\hline Lestidae & 1 & 1 & 1 & 1 & 3517 & 4127 & 36.63 & 52.01 \\
\hline Libellulidae & 2 & 1 & 2 & 1 & 3418 & 580 & 35.61 & 7.31 \\
\hline Total & 8 & 7 & 8 & 7 & 9599 & 7935 & 54.74 & 45.25 \\
\hline
\end{tabular}

Regarding the different odonatous families, the results showed that Lestidae was recorded by the highest odonatous number of individuals $(43.6 \%$ of the total number of odonatan individuals). In contrast, only $0.02 \%$ of catches was of Gomphidae representing the lowest odonatous populations.

Lestid adults were the highest odonatous number of individuals $(52.01 \%$ of the total odonatous individual number as well as lestid nymphs also was registered by the maximum population ratio (36.63\% of all catches). Conversely, the minimum nynphal and adults populations were found among both the gomphids and Aeshnids $(0.06 \%$ and $0.18 \%$, respectively) (Table, 1 ).

Regarding abundance of each species, the most abundant species was Lestes viridis representing 3517 adult individuals (36.64\% of all individuals) and 4125 nymph individuals $(52.01 \%$ of all individuals). However, the next abundant species was Crocothemis erythraea where 2376 adult (24.75\% of all individuals) were trapped. In relation to Ischnura elegans 3012 nymph individuals (37.96\% of all individuals) were captured. In contrast, the lowest abundant populations were Anax imperator and Onychogomphus fercipitus of which only 8 adults and 5 nymphs were recorded. On the other hand, one species collected as adult only called Libellula fulva where its nymphs did not appear during the present study. 


\section{II- Locality Abundance Diversity of Naiads and Adults:}

On the other hand, table (2) show abundance of odonatous populations according to the stations the encountered in. The highest population of adults was recorded in ElMashtal station in which $(33.82 \%$ of all adult individuals) was collected, while the highest populations of nymphs were recorded in Banana Island station $(25.55 \%$ of all nymph individuals). The followed highest station was Crocodile Island (23.02\% of all adult individuals) and (22.37\% of all nymph individuals). Conversely, the lowest populations were recorded in Menshaa station from which 1035 adult individuals and 1155 nymph representing $10.78 \%$ and $14.56 \%$ of all adult and nymph individuals were captured, respectively.

Table 2: The catches of Odonata from different stations at Luxor city collected during the period from March 2005 till February 2007

\begin{tabular}{|c|c|c|c|c|c|c|c|c|c|c|c|c|}
\hline \multirow{3}{*}{ Families \& species } & \multicolumn{10}{|c|}{ Stations } & \multirow{2}{*}{\multicolumn{2}{|c|}{ Total }} \\
\hline & \multicolumn{2}{|l|}{$\mathbf{B i}$} & \multicolumn{2}{|l|}{$\mathbf{C i}$} & \multicolumn{2}{|l|}{ Ma } & \multicolumn{2}{|l|}{$\mathbf{R}$} & \multicolumn{2}{|l|}{$\mathbf{M e}$} & & \\
\hline & A. & N. & A. & N. & A. & N. & A. & N. & A. & N. & A. & N. \\
\hline $\begin{array}{l}\text { Aeshnidae } \\
\text { Aeshna cyanea (Müller) } \\
\text { Anax imperator (Leach) }\end{array}$ & $\begin{array}{l}0 \\
6\end{array}$ & $\begin{array}{l}31 \\
18\end{array}$ & $\begin{array}{l}7 \\
0\end{array}$ & $\begin{array}{l}37 \\
13\end{array}$ & $\begin{array}{l}\mathbf{0} \\
\mathbf{0}\end{array}$ & $\begin{array}{l}49 \\
23\end{array}$ & 2 & $\begin{array}{c}17 \\
7\end{array}$ & $\begin{array}{l}\mathbf{0} \\
\mathbf{0}\end{array}$ & $\begin{array}{l}3 \\
1\end{array}$ & $\begin{array}{l}9 \\
8\end{array}$ & $\begin{array}{c}137 \\
62\end{array}$ \\
\hline $\begin{array}{l}\text { Coenagrionidae } \\
\text { Enalagma cyathigerum } \\
\text { (Charpentier } \\
\text { Ischnura elegans (Vander L.) }\end{array}$ & $\begin{array}{r}48 \\
394\end{array}$ & $\begin{array}{c}0 \\
844\end{array}$ & $\begin{array}{l}41 \\
622\end{array}$ & $\begin{array}{c}0 \\
755\end{array}$ & $\begin{array}{r}68 \\
518\end{array}$ & $\begin{array}{c}8 \\
795\end{array}$ & $\begin{array}{l}12 \\
299\end{array}$ & $\begin{array}{c}4 \\
319\end{array}$ & $\begin{array}{c}6 \\
209\end{array}$ & $\begin{array}{c}0 \\
299\end{array}$ & $\begin{array}{r}175 \\
2042\end{array}$ & $\begin{array}{c}12 \\
3012\end{array}$ \\
\hline $\begin{array}{l}\begin{array}{l}\text { Gomphidae } \\
\text { Onychogomphus } \\
\text { (Linnaeus) }\end{array} \quad \text { forcipiatus } \\
\end{array}$ & 138 & 4 & 113 & 1 & 126 & $\mathbf{0}$ & 40 & 0 & 13 & 0 & 430 & 5 \\
\hline $\begin{array}{l}\text { Lestidae } \\
\text { Lestes viridis (Vander L.) }\end{array}$ & 706 & 978 & 1002 & 789 & 840 & 692 & 545 & 871 & 424 & 797 & 3517 & 4127 \\
\hline $\begin{array}{l}\text { Libellulidae } \\
\text { Crocothemis erythrea (Brulle) } \\
\text { Libellula fulva (Müller) }\end{array}$ & $\begin{array}{c}424 \\
84\end{array}$ & $\begin{array}{c}152 \\
0\end{array}$ & $\begin{array}{c}361 \\
64\end{array}$ & $\begin{array}{c}180 \\
0\end{array}$ & $\begin{array}{l}930 \\
764\end{array}$ & $\begin{array}{c}95 \\
0\end{array}$ & $\begin{array}{c}361 \\
47\end{array}$ & $\begin{array}{c}98 \\
0\end{array}$ & $\begin{array}{c}300 \\
83\end{array}$ & $\begin{array}{c}55 \\
0\end{array}$ & $\begin{array}{l}2376 \\
1042 \\
\end{array}$ & $\begin{array}{c}580 \\
0\end{array}$ \\
\hline Total & 1800 & 2027 & 2210 & 1775 & 3246 & 1662 & 1308 & 1316 & 1035 & 1155 & 9599 & 7935 \\
\hline
\end{tabular}

Bi: Banana Island station

A.: Adults

Ci: Crocodile Island station $\quad$ N.: Nymphs

Ma: El-Mashtal station

R: El-Radwania station

Me: El-Menshaa station

\section{III- Periodical abundance Diversity of the odonatous insects:}

Periodical abundance of order Odonata, collectively, and three families namely: Coenagrionidae, Lestidae and Libellulidae were expressed as the seasonal abundance of their adults and nymphs during two years at five different stations as shown in tables (4, 5, 6 and 7). Because the families of Aeshnidae and Gomphidae were represented by few numbers of individuals, then it was difficult to calculate the seasonal abundance of them.

\section{1-Seasonal abundance of order Odonata, collectively:}

\section{A: Adults:}

The results showed that, the seasonal abundance of order Odonata, collectively, arrived the maximum during summer in the two years at all stations, while the lowest population occurred during spring at station all stations during the two studied years. This stability of the results probably due to adults ability adapting with the meteorological variations they face.

\section{B: Nymphs:}

Regarding the first year, the all odonatous nymphs reached their maximum abundance during winter in all studied stations. In contrast, the lowest abundance differed from station to other recording the lowest abundance in stations $\mathrm{Bi}$ and $\mathrm{Me}$ during spring, in station Ci during summer and in station during autumn.

However, during the second year, winter showed the maximum abundance in all stations except for station $\mathrm{Ma}$ in which these abundance were recorded during 
autumn. Conversely, the lowest seasonal nymph abundance was found during spring in all stations except for station Me showing dropping in abundance during summer.

2-Seasonal abundance of the different odonatous families:

A- adults:

All odonatous families showed their highest abundance during summer, while their lowest abundance was recorded during winter without exceptions in the different stations.

\section{B-Nymphs:}

The coenagrionid, lestid and libellulid nymphs showed their maximum abundance during winter of two studied years. In contrast, the minimum abundance of the two last families was during spring of two years. All stations follow the previous result with exception of station Ma exhibiting the highest and the coenagrionid lowest abundance during spring and winter, respectively, maximum and minimum lestid nymph abundance during autumn and winter, respectively.

In general, numerical diversity of the odonates and locality abundance showed little number of the odonatous species (only 9 species. This little bid number may be resulted from working on, relatively, narrow distance, or the different site had no observed variety. This result was disagree with that obtained by Abbott (2001) who worked on Distribution of dragonflies and damselflies (Odonata) in Texas and collected two hundred and five species of Odonata from Texas (USA). The last author interpreted his high recorded number as Texas contains highly diverse odonates, because of its unique geographic position and highly variable physical composition relative to other physiographic provinces.

Regarding the seasonal abundance, generally, the results indicate to importance of the two seasons, winter and spring. The highest and lowest seasonal abundance occurred during these two seasons in most studied stations. The variation of the seasonal abundance exceptive stations may not affect on the importance of winter and spring as the periods of the highest and lowest seasonal abundances because perhaps these stations, especially stations Ma, underwent some of the human activities. Therefore they were disturbed stations. Thus the seasonal abundance was not clear or accurate. These results agree with Aly et al., (1993) who found that the population of Odonata was well represented all over the year especially during winter and spring. Furthermore, Jason (2005) confirmed our results recording a drop in the odonatous individuals during July and August. In contrast, Crowley et al., (1987) disagreed with this result, where they concluded that, the maximum emergence of damselflies was occurred during spring, summer and autumn.

\section{REFERENCES}

Abbott, C. J. (2001): Distribution of dragonflies and damselflies (Odonata) in Texas. Transactions of the American Entomological Society. 127(2):189-228.

Abbott, C.J.; Behrstock, A.R. and Larsen, R.R. (2003): Notes on the distribution of Odonata in the Texas Panhandle, with a summary of new state and county records. The Southwestern Naturalist. 48 (3): 444-448.

Abdel-Aal, A.A.: Hamad, N.F.; Okasha, S.A. and Shaalan, E.A.A. (1998): Studies on the biological control and ecology of mosquitoes in Aswan Governorate: 2. Ecological studies of mosquito larvae. Assiut Veterinary Medical Journal. 39 (77): 17-35.

Abushama, F.T. (2006): Night and early morning flying insects in a residence backyard in Doha city, Qatar. Qatar University Sciences Journal. 26: 83-90. 
Ali, M.H.; Anon, M.R. and Mohammed, H.H. (2002): The seasonal variations of abundance and biomass of the two odonata naiads Ischnura evansi Morton (Odonata: Coenagrionidae) and Brachythemis fuscopalliata Selys (Odonata: Libellulidae) in the Qaramat Ali region, Basrah. Marina Mesopotamica. 17 (2): 405-415.

Alonso, E.L.P.E.; Gonzalez, S.E. and Gutierrez, Y.P.J. (2002): List and distribuation of the Odonata of River Moctezuma Basin, east-central Mexico (Insecta: Odonata). Folia Entomologica Mexicana. 41 (3): 347-357.

Aly M.Z.Y.; Hamad, N.E.F. and El-Mahdi, M.B. (1992): General survey and seasonal distribution of aquatic insects in Qena Governorate, Egypt. Bull. Fac. Sci., Assiut Univ. 21 (2-E): 65-75.

Aly, M.Z.Y.; Hamad, N.E.F. and El-Mahdi, M.B. (1993): Seasonal abundance and effect of chemo-physical factors on immature stage of order Odonata in Qena. J. Egypt. Ger. Soc. Zool. 11 (D): 77-89.

Bath, K.S. and Kaur, H. (1998): Seasonal distribution and population dynamics of aquatic insects in Harike reservoir (Punjab). J. of Ecobiology, 10 (1): 43-46.

Beschovski, V. and Marinov, M. (2007): Fauna, Ecology, and Zoogeography of Dragonflies (Insecta: Odonata) of Bulgaria. Monographiae Biologicae. 82: 199232.

Borisov, S.N. (2006): Ecological niches of species of the genus Ischnura (Odonata, Coenagrionidae) in oases of the Pamir-Alai Mountains. Entomologica Review. 86 (6): 623-631.

Brooks, S. J.( 2008): Aren't dragonflies great study organisms?. Trends in Ecology and Evolution Vol.24 No.1.

Butler, R.G. and DeMaynadier, P.G. (2007): The significance of littoral and shoreline habitat integrity to the conservation of lacustrine damselflies (Odonata). Journal of Insect Conservation: 1-11.

Crowley, P.H.; Nisbet, R.M.; Gurney, W.S.C. and Lawton, L.H. (1987): Population regulation in animals with complex life histories: Formulation and analysis of a dragonfly model. Advances in ecological Research. 17:1-59.

Finch, J.M.; Samways, M.J.; Hill, R.T.: Piper, E.S. and Taylor, S. (2006): Application of Predictive Distribution Modelling to Invertebrates: Odonata in South Africa. Biodiversity and Conservation. 15 (13): 4239-4251.

Galbreath, G.H. and Hendricks, A.C. (1992): Life history characteristics and prey selection of larval Boyeria vinosa (Odonata: Aeshnidae). Journal of Freshwater Ecology. 7: 201-207.

Gianmaria, C. (1983): Societies international Odonatologica Rapid Communications (Supplements) No. 1. Instituto di Zoologia dell' Universitā di Roma.

Hofmann, A. and Christopher, F.M. (2005): Habitat characteristics and the distribution of Odonata in a lowland river catchment in eastern England. Hydrobiologia. 539 (1): 137-147.

Jason, T.B. (2005): Community and conservation ecology of dragonfly and damselfly adults in Mississippi wetlands. M.Sc. Thesis, in Biology, Mississippi State Univ.

Kalkman, V.J.; Clausnitzer, V.; Dijkstra, B.K.D.: Orr, G.A.; Paulson, R.D. and Tol, V.J. (2008): Global diversity of dragonflies (Odonata) in freshwater. Hydrobiologia. 595 (1): 351-363.

Lorenzo-Carballa, M. O. and Cordero-Rivera, A. (2009): Thelytokous parthenogenesis in the damselfly Ischnura hastata (Odonata, Coenagrionidae): genetic mechanisms and lack of bacterial infection. Heredity, 103, 377-384. 
Katherine, Y. D.Q. (2005): Water quality assessment of a tropical freshwater marsh using aquatic insects. M.Sc. Thesis, in Biology, Puerto Rico Univ., Mayagüez Campus.

Mohamed, E.E.E. (2004): Ecological and behavioral studies on some species of order Odonata in Qena governorate (Egypt) and Northwestern (Germany). Ph.D. Thesis, Fac. Sc. Qena, South valley Uni.

Mukhrji, M.; Saha, T. and Bandyopadhaya, T.S. (2005): Diversity population and community analysis of littoral macro-invertebrate fauna of Rabindra Sarobar, Kolkata. Journal of Ecobiology. 17 (5): 401-409.

Muller, O. (1993): Observations of the evening activity of Aeshna grandis (Linnaeus, 1758) and Aeshna mixta (Latreille, 1805) Odonata, Aeshnidae. EntomologischeNachrichten-und-Berichte.37 (1): 39-44.

Norma-Rashid Y.1; Mohd-Sofian A.2; Zakaria-Ismail M.2 2001: Diversity and distribution of Odonata (dragonflies and damselflies) in the fresh water swamp lake Tasek Bera, Malaysia. Hydrobiologia, Volume 459, Numbers 1-3, pp. 135146(12).

Olsvik, H. and Dolmen, D. (1992): Distribution, habitat, and conservation status of threatened Odonata in Norway. Fauna Norvegica, Series B. 39(1): 1-21.

Osman, K. S.M. (2004): On the ecology of insect species composition encountered in three natural protectorates of the Red Sea Governorate, Egypt. J. Union Arab Bio. Cairo. 22 (A): 405-432.

Raab, R. (2004): The dragonflies (Insecta: Odonata) of a dynamic floodplain of the River Danube near Regelsbrunn (Lower Austria). Abhandlungen der-ZoologischBotanischen-Gesellschaft-in Osterreich. 34: 99-122.

Samways, M.J. and Steytler, N.S. (1996): Dragonfly (Odonata) distribution patterns in urban and forest landscapes and recommendations for riparian management. Biological-Conservation. 78 (3): 279-288.

Schultz, H.; Waringer, J.A. and Chovanec, A. (2003): Assessment of the ecological status of Danubian floodplains at Tulln (Lower Austria) based on the Odonata Habitat Index (OHI). Odonatologica. 32 (4): 355-370.

Shoukry, I.F.I. (1979): Survey and taxonomy of Odonata in A.R. Egypt. M.Sc. Fac. Sci., Ain Shams Uni..

Shukla, A.N. and Shrivastava, S. (2003): Observations on macrozoobenthos saprobiety index with relation to pollution status of Gandhisagar reservoir in Madyha Pradesh. Uttar-Pradesh-Journal of Zoology. 23 (3): 185-190.

Stoks, R. and McPeek, M.A. (2003): Predators and life histories shape Lestes damselfly assemblages along a freshwater habitat gradient. Ecology. 84 (6): $1576-1587$.

Tawfik, M.F.S.; El-Husseini, M.M. and Abou-Bakr, H. (1986): Ecological observations on aquatic insects attacking mosquitoes in Egypt. Bull.de la Societe Ento. d' Egypte. (66): 117-126.

Vantol, J. and Rozendaal, F.G. (1995): Records of Calopterygoidea from Vitnam, with descriptions of two new species (Zygoptera: Amphipterygidae, Calopterygidae, Chlorocyphidae, Euphaeidae). Odonatologica. 24 (1): 89-107.

Vick, G.S. (2002): Preliminary biodiversity assessment of the Odonata fauna of the Takamanda Forest Reserve, Can

\section{I} "JF-Report. 4(1): 1-10.

A

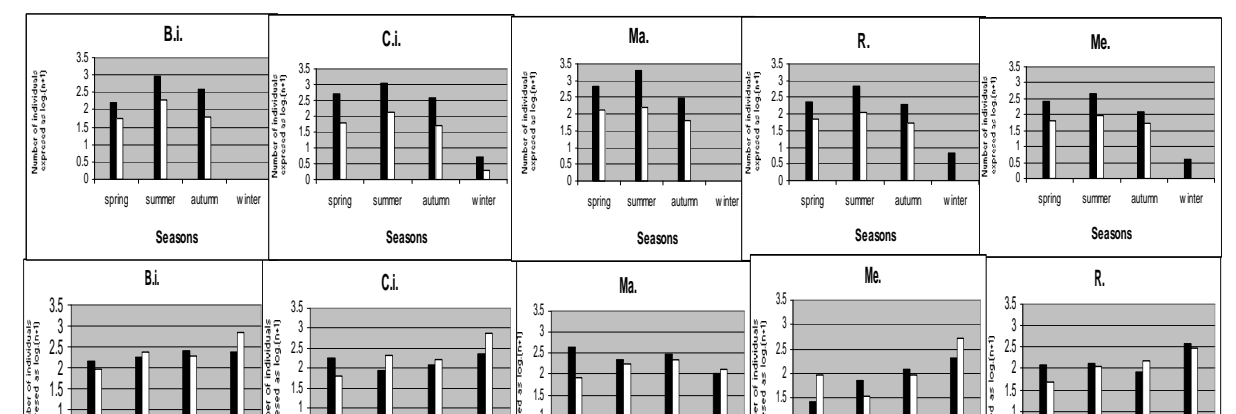


B

Fig. 4: Distribution of A) adults and B) nymphs of: I) All of order Odonata and families II) Coenagrionidae; III) Lestidae and IV) Libellulidae at stations (Bi), (Ci), (Ma), (R) and (Me) in the first year ( $\mathbf{a})$ and in the second year $(\square)$. 
دراسة تنوع الاطوار اليافعة وغير اليافعة من رتبة الرعاشات التى تم جمعها من نهر النيل فى منطقة جنوب مصر

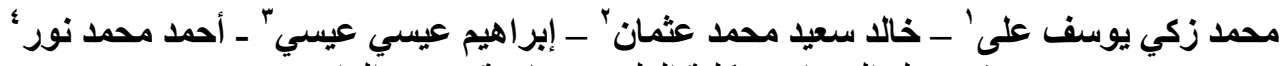

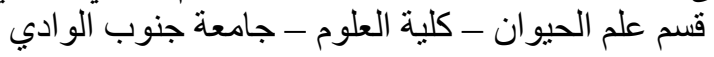

يهذف هذا البحث الى دراسة تنوع الاطوار اليافعة و الغير يافعة من رنبة الرعانثات التى تم جمعها من

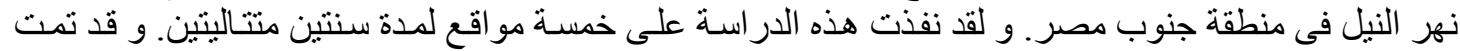

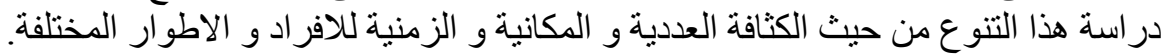

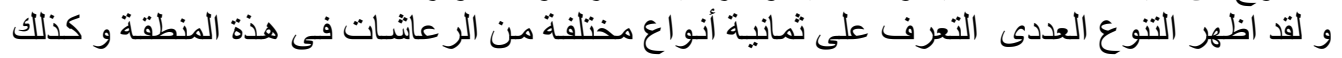

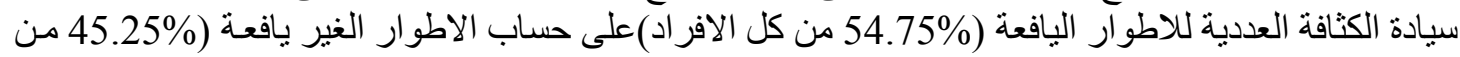

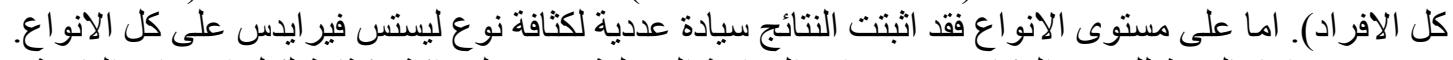

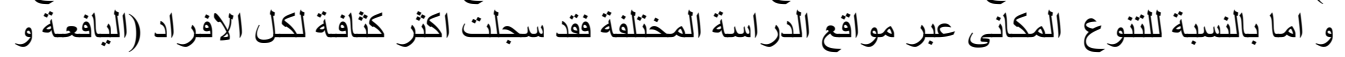

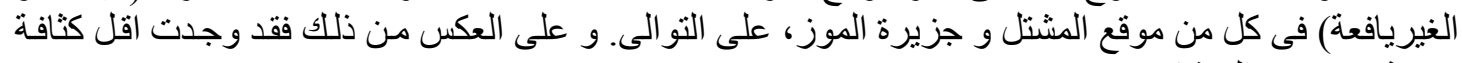
عددية فى موقع المنشاة.

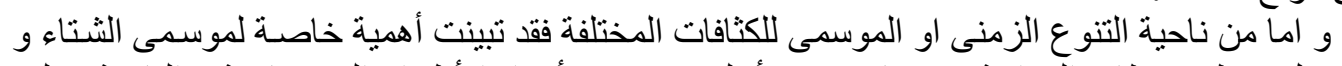

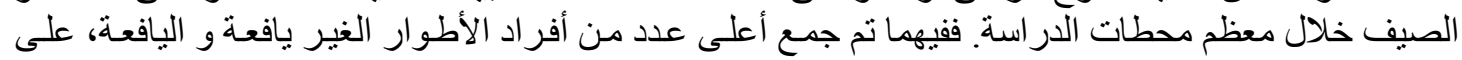

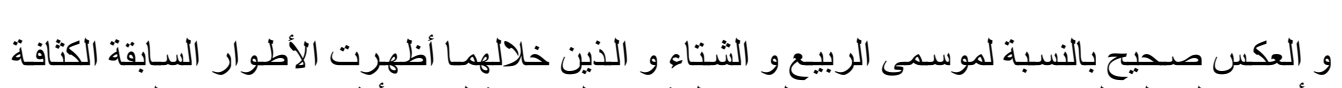
الترتيب.

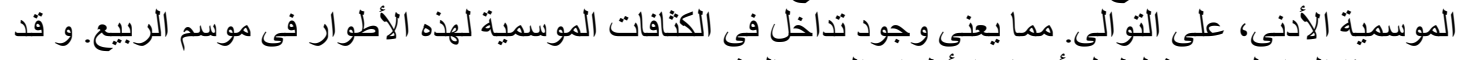

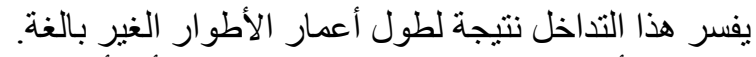

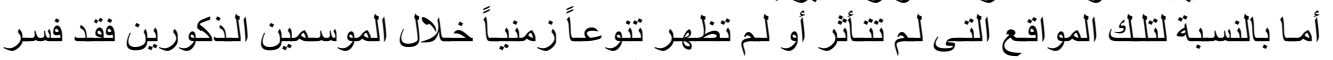

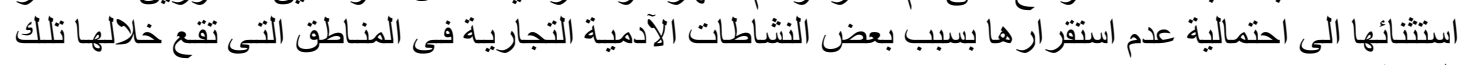

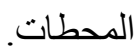

